\title{
MEASUREMENTS ON THE THERMAL EXPANSION OF FUSED SILICA
}

\author{
By Wilmer Souder and Peter Hidnert
}

\begin{abstract}
This paper gives the results of an investigation on the thermal expansion of transparent and nontransparent fused silica for various temperature ranges between -125 and $+1,000^{\circ}$ C. A total of 48 expansion tests were made on 17 samples of fused silica.

A detailed description of the apparatus and the methods used in this research and a summary of available data obtained by previous observers on the thermal expansion of fused silica are given.

A critical temperature or minimum length was found at about $-80^{\circ} \mathrm{C}$. Expansion occurred on heating fused silica above the critical temperature or cooling below this temperature. The coefficients of expansion of the transparent samples differ slightly from the coefficients of the nontransparent samples. Typical expansion curves are shown and discussed. The authors' average expansion curve is compared with the results of previous investigators. The table in the summary gives a résumé of average coefficients of expansion derived from the data on all samples for various temperature ranges between 20 and $1,000^{\circ} \mathrm{C}$.
\end{abstract}

\section{CONTENTS}

Page

I. Introduction

II. Previous determinations._.

III. Materials investigated......... 7

IV. Apparatus and methods

V. Results._._.

1. Low temperature ranges.

2. Moderate temperature ranges _.

3. High temperature ranges._._.

VI. Comparison of results... 21

VII. Summary

VIII. Selected bibliography of expansion apparatus._... 23

\section{INTRODUCTION}

The fact that the thermal expansion of fused silica (fused quartz) is exceedingly small attracted many investigators to a study of this remarkable material. It was first made by $\mathbf{M}$. Gaudin ${ }^{1}$ in 1839 , but the great value of this useful material was not recognized until about 50 years later. 
The present investigation was undertaken for the purpose of obtaining additional data on the linear thermal expansion of fused silica for use in thermostats, clock pendulums, length standards, pyrometers, gas-sampling devices, acid-resisting articles, insulating and temperature resisting devices, etc. Expansion tests were made over various temperature ranges between -125 and $+1,000^{\circ} \mathrm{C}$. Seventeen samples of fused silica were examined, on which a total of 48 tests were made.

A summary of available data obtained by previous observers on the thermal expansion of fused silica and a detailed description of the apparatus and methods of measurement required for the exceedingly difficult determinations of the small coefficients of expansion are included.

The authors wish to express their appreciation for the cooperation by the Thermal Syndicate (Ltd.), Brooklyn, N. Y., and the General Electric Co., Schenectady, N. Y. These companies furnished samples and information about the preparation, chemical composition, etc. Acknowledgment is also due to W. T. Sweeney and J. F. Fox, Bureau of Standards, for assistance in the investigation.

\section{PREVIOUS DETERMINATIONS}

Le Chatelier, Callendar, Holborn and Henning, Chappuis, Scheel, and later investigators have done work on the thermal expansion of fused silica. Most of the previous observers made determinations on a single specimen of lused silica (or on a few samples only). Some observers state that their samples were annealed, but fail to describe how this was accomplished. The present writers were unable to find an authoritative statement regarding the proper method of annealing ${ }^{2}$ fused silica.

Since a complete review of all available work on fused silica would require considerable space, it was decided to present a summary of expansion data (see Table 1). In this summary, o $a_{t}$ represents the average coefficient of expansion between $0^{\circ}$ and $t^{\circ} \mathrm{C}$., $L_{\mathrm{t}}$ represents the length at $t^{\circ} \mathrm{C}$. and $L_{\mathrm{o}}$ the length at $0^{\circ} \mathrm{C}$. For additional information the reader should refer to the original papers.

Values in Table 1 should not be confused with values for crystalline quartz, the expansions of which are variously giren from 15 to 35 times as great as those for the fused material.

\footnotetext{
${ }^{2}$ The Thermal Syndicate (Ltd.) recently stated that from their observations upon the behavior of fused quartz, particularly the variation in its mechanical properties (Young's modulus and shear modulus), they incline to the belief that annealing can not be at all complete below $1,050^{\circ} \mathrm{C}$. unless with very prolonged beating.
} 


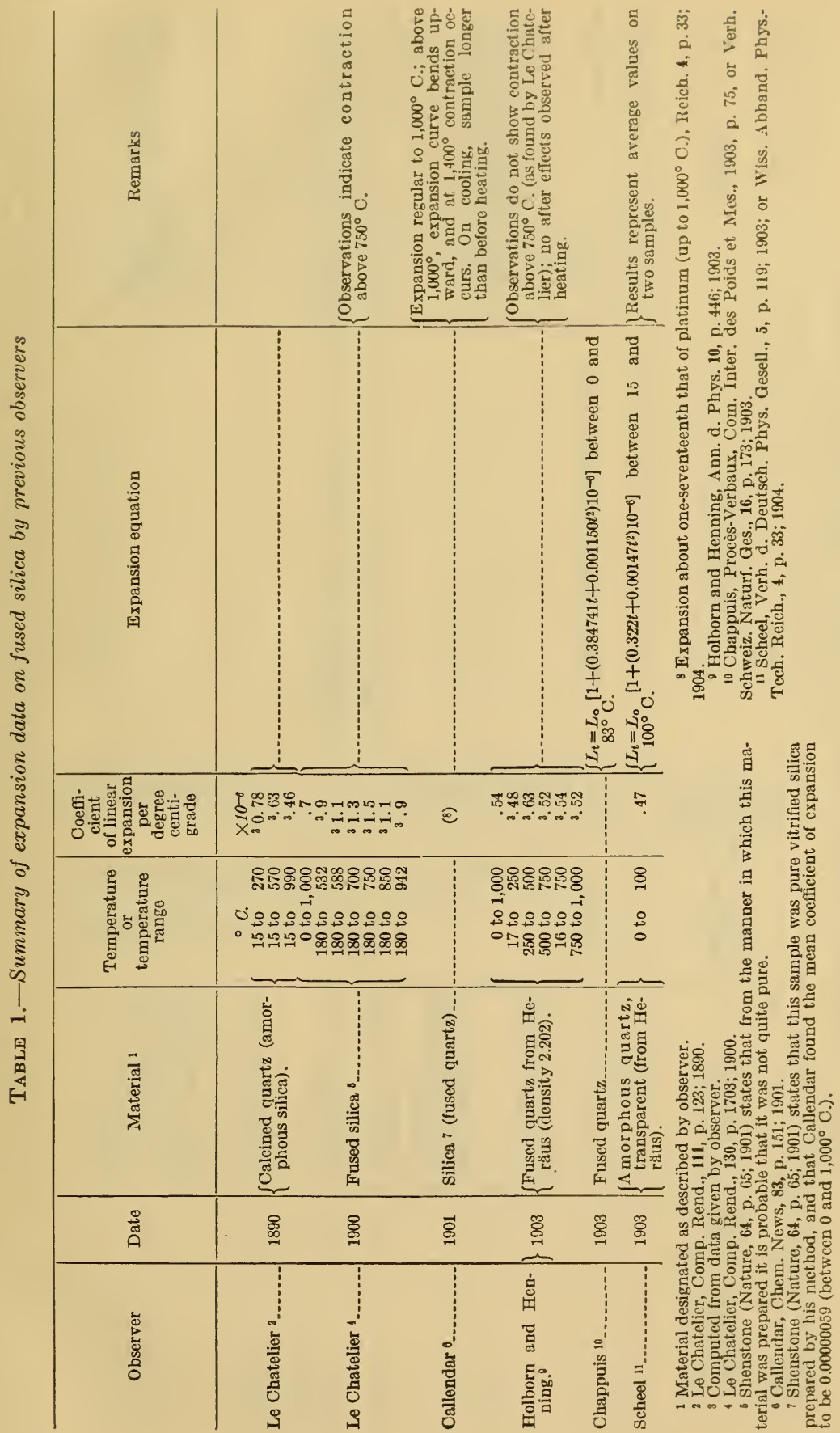




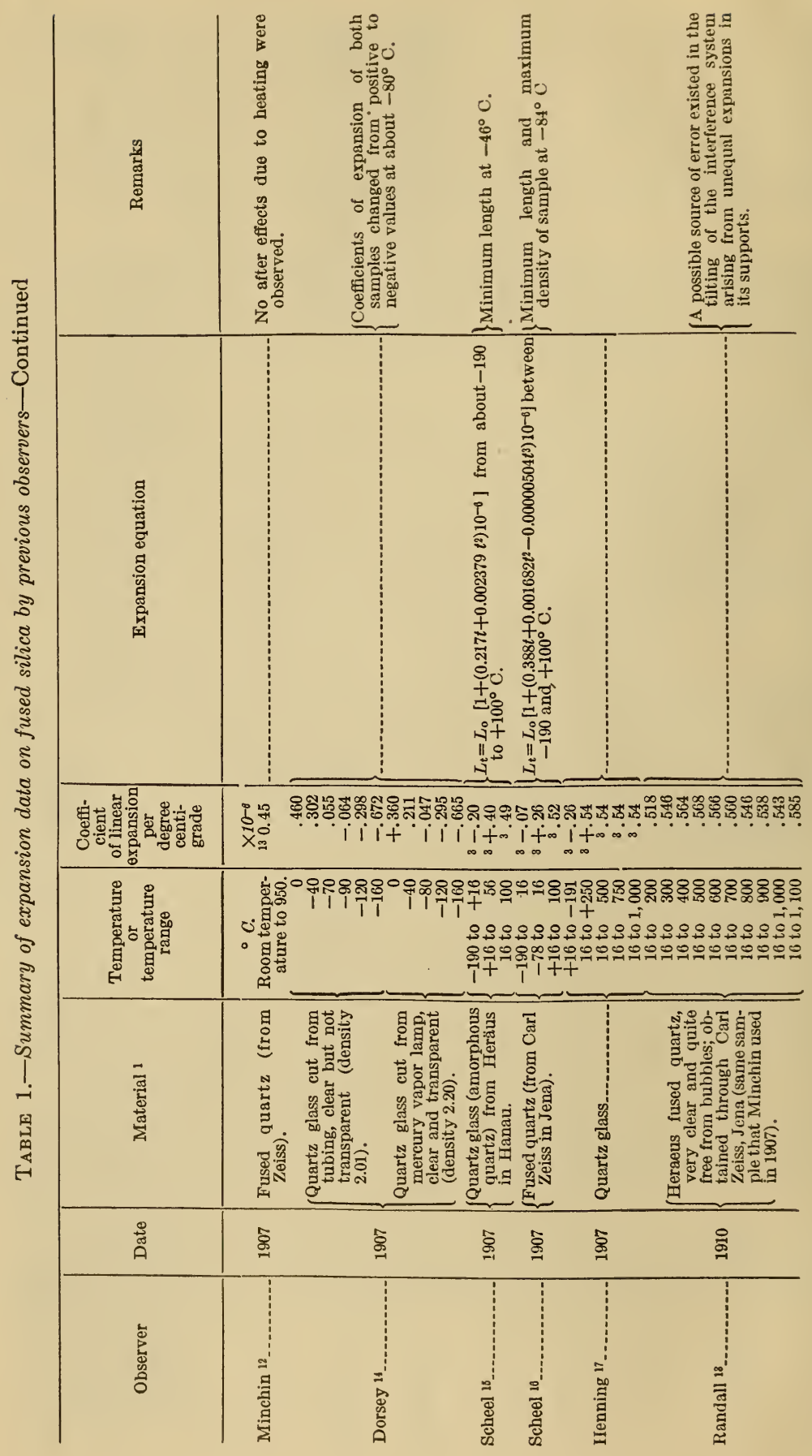



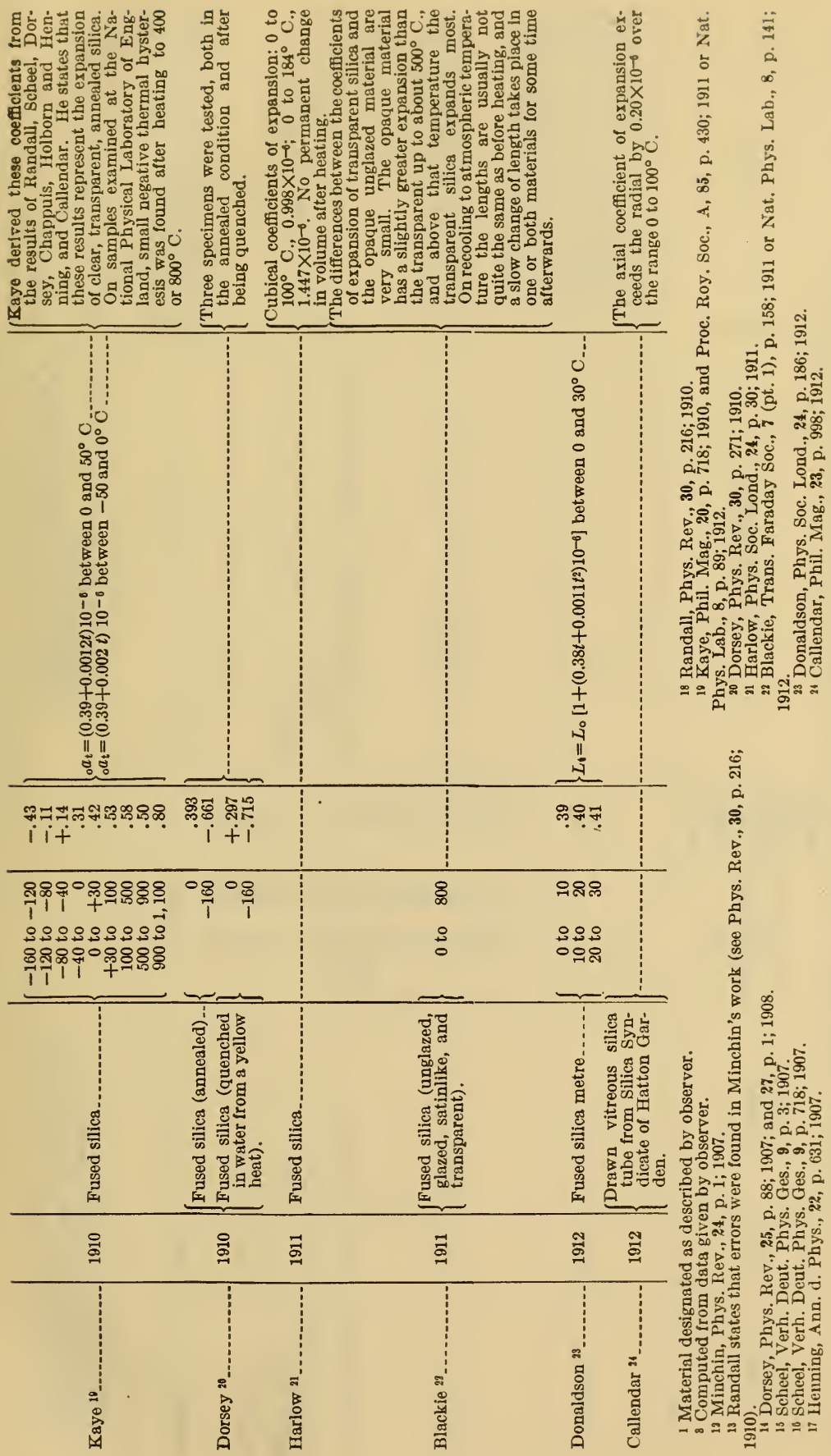


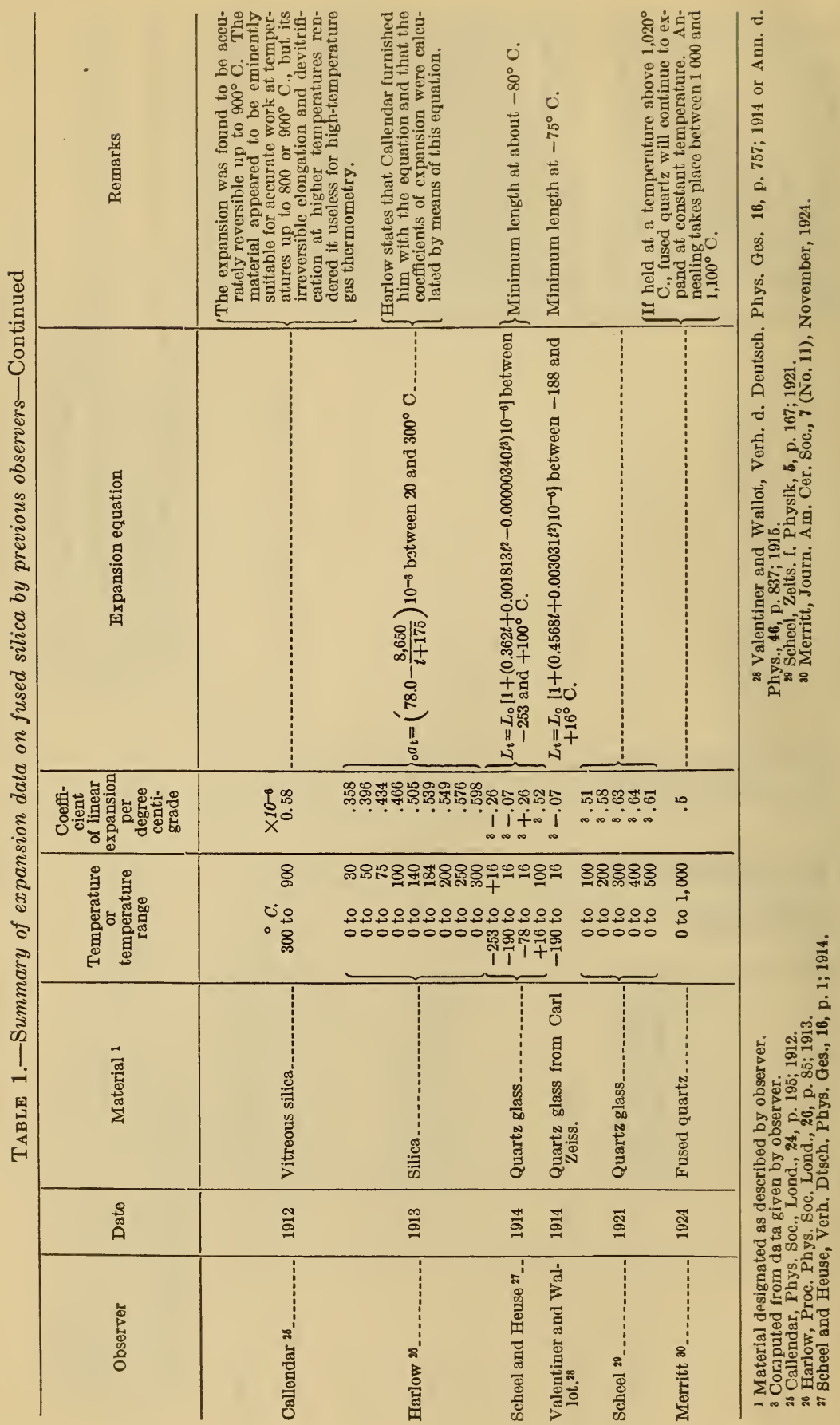




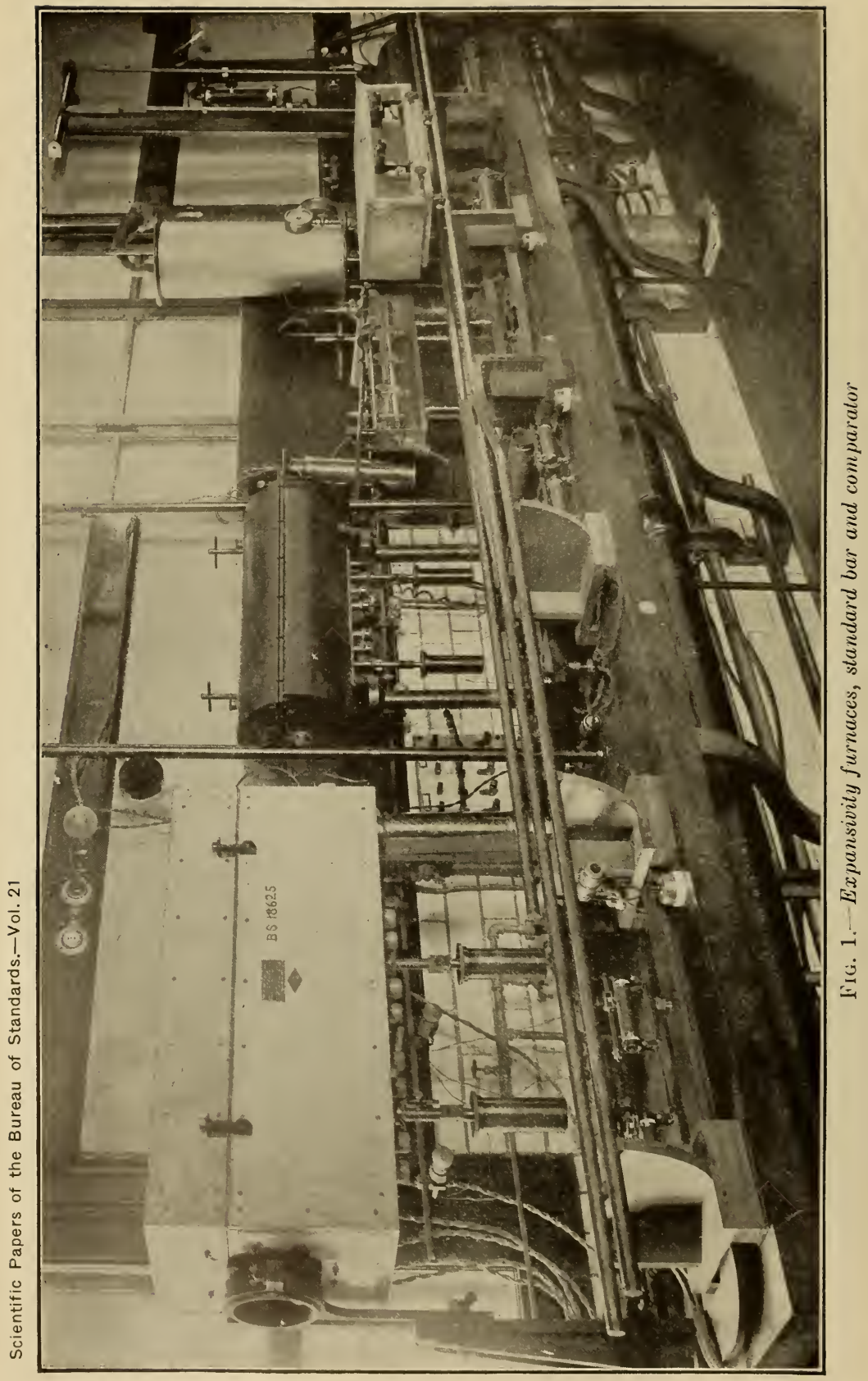




\section{MATERIALS INVESTIGATED}

Seventeen samples of fused silica were investigated. A total of 48 expansion tests were made on theso specimens. Tho results obtained were divided into three groups, according to the temperature ranges over which the samples were examined.

All specimens for this investigation were furnished by the Thermal Syndicate (Ltd.), Brooklyn, N. Y., except.samples 56, 1102, 1102A, and 1102B. Sample 56 was obtained from Charles Engelhard, New York, N. Y., and samples 1102, 1102A, and $1102 \mathrm{~B}$ were obtained from General Electric Co., Schenectady, N. Y.

Before expansion tests were made on some specimens (to be mentioned later) they were heat treated by the authors. These samp!es were all heat treated at the same time in an electric furnace. The procedure was as follows:

Samples were heated to $1,000^{\circ} \mathrm{C}$. in four hours and kept at this temperature for two hours. Allowed to cool overnight to $800^{\circ} \mathrm{C}$. Temperature then raised to $1,000^{\circ} \mathrm{C}$. and held for two hours. Allowed to cool overnight to $800^{\circ} \mathrm{C}$., cooled slowly to $650^{\circ} \mathrm{C}$., and finally cooled in furnace with current off.

Descriptions of the various samples will be given in the proper sections. The Thermal Syndicate (Ltd.) stated that the differences in appearance of some of their specimens of fused silica were produced through the inclusion of more or less minute air bubbles.

\section{APPARATUS AND METHODS}

The equipment and methods used for making thermal expansivity tests at this bureau are the result of no one individual's efforts. There are four or more laboratories equipped for as many types of determinations. The volumetric and density laboratory, the length laboratory, the interferometry laboratory, and the thermal expansivity laboratory are each equipped for certain types of thermal expansion work. The apparatus described in this paper is that used in the thermal expansivity laboratory and represents the developments of ideas of a number of former workers (Gray, Schad, and associates) and the authors of this paper.

The accuracy of this equipment is believed to be superior to the accuracy of any other equipment used for similar purposes. While it is not possible to specify precisely the accuracy of work on expansion, there are indications that, under favorable conditions, an accuracy of one-tenth of 1 per cent is secured in the determinations of coefficient of expansion. The fact that a specimen may retrace the expansion curve of a previous test or that all points in the curve fit a second degree equation do not necessarily guarantee absolute correctness of determination. Independent tests on supposedly duplicate specimens furnish a fairly good, though not conclusive, idea $78559^{\circ}-26 \dagger-2$ 
of accuracy. The value, one-tenth of 1 per cent, stated above is selected as a fair representation of the three criteria mentioned

The equipment is divided into two types: (1) The air type heating chamber, shown at the left of Figures 1 and 2, in which the specimen is surrounded by air or gas; and (2) the bath type chamber, shown at the right of Figures 1 and 2, in which the specimen is surrounded by a liquid used in heating or cooling.

In both types heating is effected by electric current passing through heating coils. Likewise both types are equipped with thermocouples and a potentiometer for measuring temperatures. Cooling for lowtemperature tests is secured in the bath type by expanding compressed air from a liquid air interchanger through coils immersed in the bath.

The positions of the ends of the specimens in the air chamber are indicated by fine wires hanging vertically from the ends of the specimen through slots in the bottom of the chamber and weighted to remove all curvature. Two micrometer microscopes mounted horizontally on a traveling comparator and separated by a lateral distance equal to the length of the specimen are used to follow the length
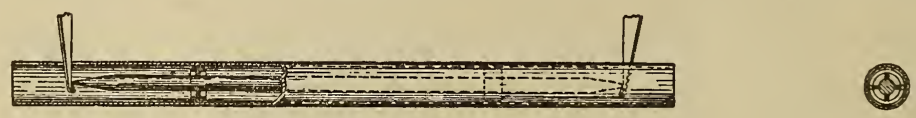

FIG. 3.-Specimen, specimen holder, and contact fingers for vertical position wires as used in bath furnace

changes of the specimen. Manifestly the length changes of the specimen are the same as the changes in separation of the two rertical wires hanging freely from the ends of the specimen. In the bath type chamber the wires extend upward from a finger support placed beneath the ends of the specimen (see fig. 3). Here the length increments of the specimen are proportional to the changes in wire separations. More minute details will be found on the following pages.

The apparatus as shown requires a specimen $300 \mathrm{~mm}$ long. This length usually eliminates the effects of possible inhomogeneities of sample. Provision has been made for handling longer and shorter specimens. The limits of length are the length of the furnace for long specimens and the limit of contact approach of the two micrometer microscopes for the short specimens. Diameters between 5 and $11 \mathrm{~mm}$ are most satisfactory.

Materials are usually shaped as shown in Figure 4. The radius of curvature at the ends should be about $15 \mathrm{~cm}$. When the specimens are carried to a temperature where oxidation or scaling is expected, the furnace should be filled with a protective gas, such as nitrogen or forming gas. When this protection is not available, it is possible to minimize the effects by placing the position wires in sharp $\mathbf{V}$ grooves 

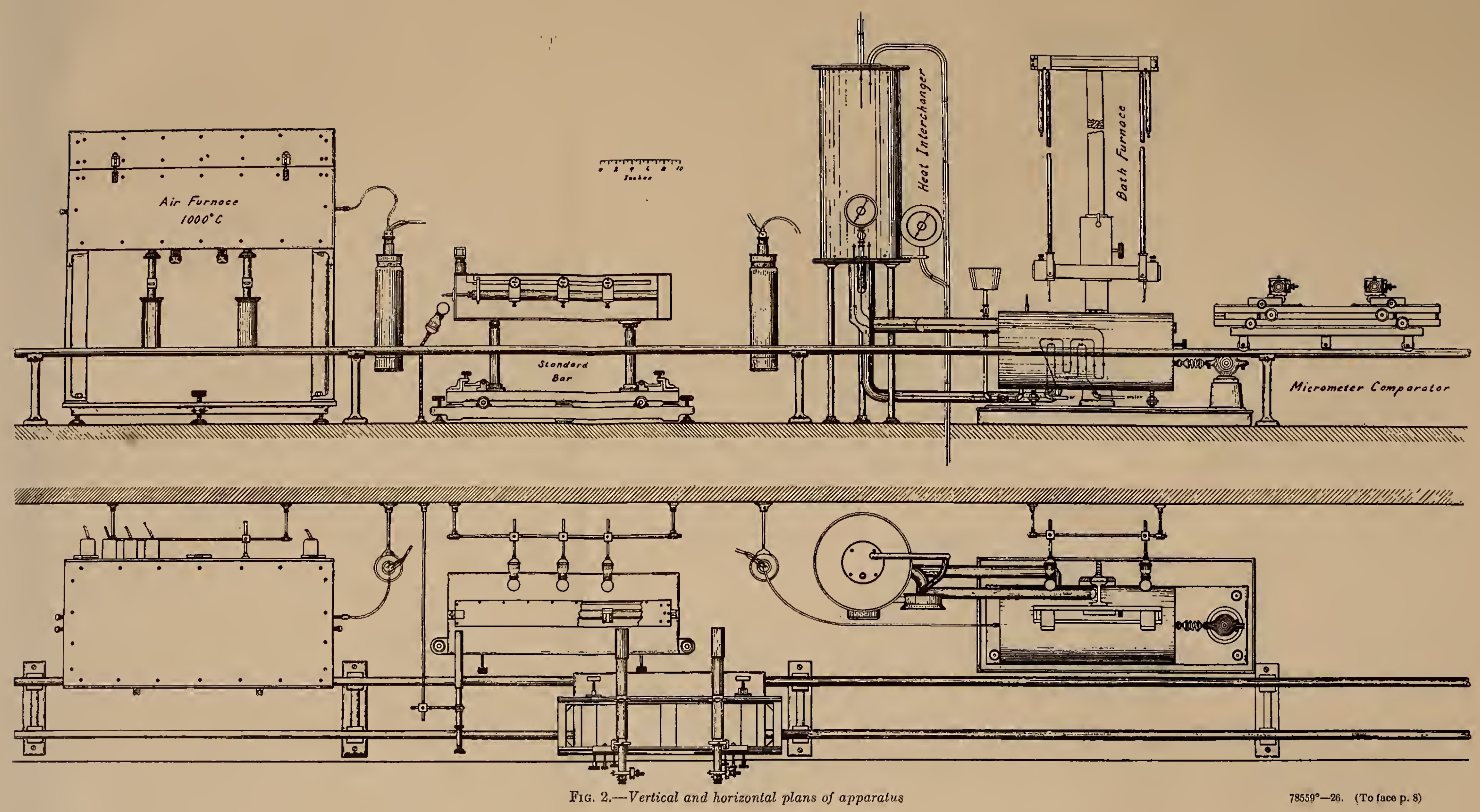
cut around the specimen, as shown in Figure 5. The weights attached to the wires are suspended in oil to damp out vibrations from the building or surroundings. The masses of these weights vary from 5 to $25 \mathrm{~g}$ each. For the higher temperature runs a set of the lighter weights are used. The wires are always annealed, in position, before observations are made. The annealing is done by passing electric current through the wires. For tests below $700^{\circ}$ C., 0.001 or 0.002

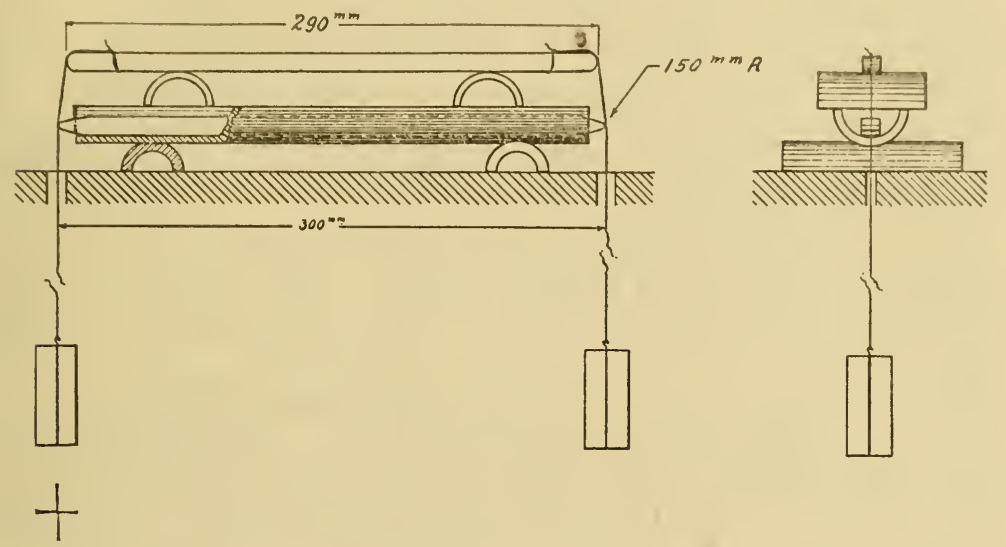

FIG. 4.-Details of specimen mounting for use in air furnace

inch diameter chromel wires are used. For tests above $700^{\circ} \mathrm{C}$, platinum-osmium (about $62 / 3$ per cent Os) wires 0.002 inch in diameter give satisfactory service. The wires in the bath furnace are 0.001 inch tungsten.

The bath furnace, by reason of the circulation and intimate contact of the heated or cooled liquid, permits more rapid observations than the air type. Observations are recorded when the specimen has reached the temperature of the furnace. This may be determined
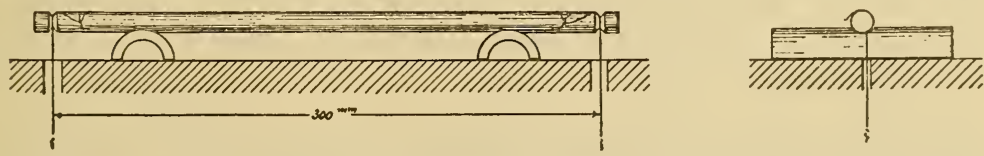

FIG. 5.-Method of mounting specimens which oxidize or scale during test

by trial readings of the length changes over an interval of time during which the temperature of the furnace is kept constant. After readings are completed the heating current is adjusted for the next interval. The immersion of specimens in the liquid bath is limited to those specimens not attacked by the liquids used. The usual practice is to use a light engine oil (which does not give off offensive odors) for the temperature range 20 to $300^{\circ} \mathrm{C}$. For the range -50 to $+40^{\circ} \mathrm{C}$. gasoline is used and for the range -150 to $+20^{\circ} \mathrm{C}$. 
pentane is employed. It is very important that all construction be so arranged that the oil, gasoline, or pentane will drain completely when the changes are made. Water coils wound near the heating coils in the bath chamber have been found very efficient in reducing temperatures when additional specimens are to be tested in rapid succession, or when data are taken on cooling from the high temperatures.

The vertical position wires are illuminated by 10-watt mazda frosted spherical lamp bulbs. Resistances in the lamp circuit are used to reduce the illumination to a satisfactory intensity. By placing parallel spider lines in the reticle of the microscope to caliper the position wires an excellent arrangement for high-precision measurements is secured.

The air furnace in Figure 2 has external control rheostats for each side and end of the heating chamber. The external heat loss from these rheostats is reduced by using a transformer for the lower temperature tests.

With all furnaces it is essential that the horizontal condition of the specimen shall not change during the test. A further precaution. for the bath furnace requires that the readings be made at a known distance above the end of the specimen and that the exact ratio of distances-level of observation to upper support of wires and end of specimens to upper support of wires-be known and maintained.

Specimens which have a tendency to warp on heating can be placed in a glass tube or between plates. Tests on such specimens are not considered to be satisfactory. The change in length of materials incident to the heat treatment of the test is recorded as the difference between the room temperature observations before and after the test. Verification of this change is afforded by readings of a micrometer caliper used to secure the length of the specimen before mounting in, and after removal from, the furnace. This value is often of importance in verifying an imperfect annealing of the specimen or establishing the percentage growth or shrinkage due to chemical changes.

A definite idea of the arrangement of the equipment is to be secured from the photograph of furnaces and comparator reproduced in Figure 1. Figure 2 shows vertical and horizontal plans of the apparatus. The air type heating chamber or furnace is shown at the left of the figures. A second air-heating furnace appears in the photograph (fig. 1), but not in Figure 2. The standard bar and micrometer comparator appear in front of the window (fig. 1). The interchanger and bath furnace are partially visiblo near the right margin of Figure 1. Vacuum bottles used in icing the thermocouple junctions appear at the right of two furnaces in Figure 1. Comnections to the potentiometer are made through lead-covered 
cables and a selector switch. Triple junctions are placed in the air furnaces. The forced circulation of the bath liquid in the third furnace, by a motor and propeller, maintains uniformity of temperature throughout; hence a single thermal junction is sufficient. Platinum-platinum rhodium couples are used for the $1,000^{\circ} \mathrm{C}$. air furnace. For the second, or $600^{\circ}$ C. air furnace (shown in fig. 1 but not in fig. 2), a gold palladium-platinum rhodium couple is used. The cooling tests, usually made in the bath furnace and the short range of temperature, -150 to $+300^{\circ} \mathrm{C}$., permit the use of the more sensitive copper constantan couple in the third furnace. The interchanger is of the regular air-liquifying type. The cooled air, compressed to about $2,500 \mathrm{lbs}$./in. ${ }^{2}$ is expanded through coils in the bath furnace when low temperatures are required.

Figure 3 shows the method of mounting specimens for inserting and locking in the bath furnace. Figure 4 represents one method of support for the other furnaces. The top bar forms a support for the position wires and allows them to pass the ends of the specimen without introducing a sharp bend and, perhaps, slight error, as would be the case if the wires were wrapped around the specimen to be tested. The supports for the specimen are split tubes of fused silica. The procedure for taking observations is as follows:

1. The micrometer comparator is set to a definite interval on the standard bar, approximately equal to to the length of the specimen. This interval will be used later to evaluate any intentional change in the comparator. Intentional changes are often necessary; for example, for materials of high expansivity tested over any considerable temperature interval. In this instance the actual separation of the position wires suspended from the specimen will pass beyond the field of view of the micrometer.

2. The comparator is then moved to position for viewing the wires from the specimen. Settings of the micrometer heads are made and recorded. This value is taken as the fiducial length of specimen. The comparator is usually returned to the standard bar for verification.

3. After a definite predetermined temperature change of the specimen, readings are again made on the standard bar and specimen. Observations at definite temperatures are usually taken, and when regularity of expansivity is evident it is customary to derive a second or third degree equation from the data. From this equation coefficients of expansion may be computed for desired temperature intervals.

Manifestly a number of refinements are necessary for data of high order. These require corrections for the changes in length on the standard bar due to changes in room temperature, corrections for 
lack of uniformity of micrometer screw, and care to maintain a constant temperature of the specimen during observations.

The above description will give a fairly definite idea of the equipment and methods used for precision expansivity tests. Manifestly such refinements are not required by all laboratories. The selecterl bibliography at the close of this publication will give references to a number of types of expansivity equipment. From this list more simple equipment may be sclected, but, as stated in a previous paragraph, it is believed that the apparatus described in this paper possesses superior accuracy for tests to which it is adapted.

For laboratories interested in more exact details of construction blue prints are on file and will be loaned upon request.

\section{RESULTS}

For convenience, the results obtained will be given in the following three subsections: (1) Low temperature ranges (between $-125^{\circ} \mathrm{C}$. and room temperature). (2) Moderate temperature ranges (between room temperature and $300^{\circ}$ C.). (3) High temperature ranges (between room temperature and $1,000^{\circ}$ C.).

All coefficients of expansion were obtained from the observations on heating, except those noted otherwise.

\section{LOW TEMPERATURE RANGES}

Expansion determinations were made on three samples of transparent fused silica between room temperature and about $-125^{\circ} \mathrm{C}$. in a bath containing pentane. The following information relating to these samples was furnished by the manufacturers:

(a) Samples 1056A and 1057 are practically pure $\mathrm{SiO}_{2}$. The total impurities will not exceed 0.1 per cent, and even with this quantity of impurities the iron content must be practically zero. The impurities are probably very small quantities of alumina or lime. The $\mathrm{SiO}_{2}$ was heated in an electric furnace to about $2,200^{\circ} \mathrm{C}$., and the melt thus obtained was expanded by air pressure to fill confining molds. In preparing samples of fused silica they may be reheated locally at times to re-fuse certain portions.

(b) The chemical composition of sample 1102B consists of almost 100 per cent water-clear crystal quartz. The crystals after cleansing with acid and removing outside impurities were cracked into small pieces and fused. The fused mass was allowed to cool in the furnace for one or two hours. The fused slug was then remelted at atmospheric pressure and the molten mass finally run through a die into the air and cooled quickly.

The expansion observations are shown graphically in Figure 6. The results may be represented by the empirical equations giren in Table 2. In these equations, which were derived by the method of least squares, $\Delta L$ represents the expansion or change in length from the lowest temperature to any temperature $t$ between the minimum temperature and room temperature. 
TABLE 2.-Expansion equations at low temperatures

\begin{tabular}{|c|c|c|c|c|}
\hline Sample & Aaterial & $\begin{array}{l}\text { Tempera- } \\
\text { ture range }\end{array}$ & Expansion equation & $\begin{array}{l}\text { Probable } \\
\text { error of } \\
\Delta L\end{array}$ \\
\hline $1056 \mathrm{~A} \ldots$ & $\begin{array}{l}\text { Fused silica rod, } 8 \\
\text { mm diumeter, } \\
\text { heat treated. } 1\end{array}$ & $\begin{array}{c}{ }^{\circ} C \\
-125 \text { to }\end{array}$ & $\Delta L=\left[-0.059(t+125.4)+0.001039(t+125.4)^{2}\right] 10^{-0} \ldots$ & $\pm 0.000003 s$ \\
\hline $1057 \ldots$ & $\begin{array}{l}\text { Fused silica rod, } 6 \\
\text { mu diameter, } \\
\text { annealed.? }\end{array}$ & -130 to +19 & $\Delta L=\left[-0.223(t+130.1)+0.002161(t+130.1)^{2}\right] 10^{-6} \ldots$ & \pm .0000020 \\
\hline $1102 B^{3}$ & $\begin{array}{l}\text { Fused silica rod, } 5 \\
\text { mum diameter, } \\
\text { not annealed. }\end{array}$ & -123 to +20 & $\Delta L=\left[-0.612(t+127.9)+0.004063(t+127.9)^{2}\right] 10^{-0} \ldots$ & \pm .0000020 \\
\hline
\end{tabular}

1 Sce Section III

Annealed by Thermal Syndicate (Ltd.).

8 Data on this sample were obtained from the observations on cooling.

The expansion curves of the preceding figure snow very interesting results. For each sample of fused silica a critical temperature (or

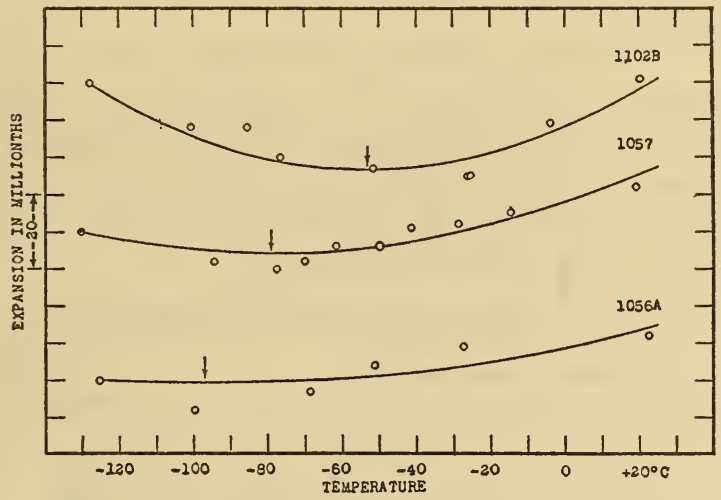

FIG. 6.-Linear expansion of three samples of fused silica at low temperatures

Arrows indicate critical temperatures (or minimum length)

minimum length) was found. On heating above this temperature the material expands, but on cooling below this temperature expansion (instead of contraction, as might be expected) also takes place. In other words, the coefficients of expansion are positive above the critical temperature and negative below this temperature. The data given in the following table were computed from the preceding equations.

TABLE 3.-Critical temperatures and coefficients of expansion

\begin{tabular}{|c|c|c|c|}
\hline \multirow[b]{2}{*}{ Sample } & \multirow[b]{2}{*}{$\begin{array}{c}\text { Critical } \\
\text { tempera- } \\
\text { ture }\end{array}$} & \multicolumn{2}{|c|}{$\begin{array}{l}\text { A verage coefficients } \\
\text { of expansion per } \\
\text { degree centigrade }\end{array}$} \\
\hline & & $\begin{array}{c}\text { From } \\
-125^{\circ} \mathrm{C} \text {. } \\
\text { to criti- } \\
\text { cal } \\
\text { tempera- } \\
\text { ture }\end{array}$ & $\begin{array}{c}\text { From } \\
\text { critical } \\
\text { tempera- } \\
\text { ture } \\
\text { to }+20^{\circ} \\
\mathrm{C} .\end{array}$ \\
\hline $\begin{array}{l}1056 \mathrm{~A} \ldots \ldots \\
1057 \ldots 2 \mathrm{~B} \\
1102 \mathrm{~B}\end{array}$ & $\begin{array}{l}C . \\
-97 \\
-79 \\
-53\end{array}$ & $\begin{array}{r}\times 10^{-6} \\
-0.03 \\
-.10 \\
-.30\end{array}$ & $\begin{array}{l}\times 10-0 \\
+0.12 \\
+.21 \\
+.29\end{array}$ \\
\hline
\end{tabular}


Previous observers (Dorsey, Scheel, Scheel and Heuse, and Valentiner and Wallot) found critical temperatures between -46 and $-84^{\circ} \mathrm{C}$. The results of the present investigation indicate that the critical temperatures are between -53 and $-97^{\circ} \mathrm{C}$. These variations are evidently due to differences in the samples. From a consideration of all available results relating to the critical temperature or minimum length of fused silica $-80^{\circ} \mathrm{C}$. may be taken as a representative value for the critical temperature of this material. Variations from this value are to be expected, due to variations in different samples.

The preceding equations may be transformed, as follows: For $1056 \mathrm{~A}$

for 1057

and for $1102 \mathrm{~B}$

$$
L_{\mathrm{t}}=L_{\mathrm{o}}\left[1+\left(0.202 t+0.001039 t^{2}\right) 10^{-6}\right]
$$

$$
L_{\mathrm{t}}=L_{\mathrm{o}}\left[1+\left(0.339 t+0.002161 t^{2}\right) 10^{-8}\right]
$$

$$
L_{\mathrm{t}}=L_{\mathrm{o}}\left[1+\left(0.427 t+0.004063 t^{2}\right) 10^{-8}\right]
$$

where $L_{t}$ represents the length of the material at any temperature $t$ within the proper temperature limits and $L_{\mathrm{o}}$ the length at $0^{\circ} \mathrm{C}$.

Table 4 gives the rates of expansion (or instantaneous coefficients) of the samples of fused silica at various temperatures. These values

\begin{tabular}{|c|c|c|c|}
\hline \multirow{2}{*}{ Temperature in degrees centigrade } & \multicolumn{3}{|c|}{ Rates of expansion } \\
\hline & $1056 \mathrm{~A}$ & 1057 & $1102 \mathrm{~B}$ \\
\hline $\begin{array}{l}-120 \\
-100 \\
-80 \\
-60\end{array}$ & $\begin{array}{r}\times 10^{-6} \\
-0.05 \\
-.01 \\
+.04 \\
+.08\end{array}$ & $\begin{array}{r}\times 10-0 \\
-0.18 \\
-.09 \\
-.01 \\
+.08\end{array}$ & $\begin{array}{r}\times 10^{-6} \\
-0.55 \\
-.38 \\
-.22 \\
-.06\end{array}$ \\
\hline $\begin{array}{l}-40 \\
0_{0} 20 \\
+\end{array}$ & $\begin{array}{l}+.12 \\
+.16 \\
+.20 \\
+.24\end{array}$ & $\begin{array}{l}+.17 \\
+.25 \\
+.34 \\
+.43\end{array}$ & $\begin{array}{l}+.10 \\
+.26 \\
+.43 \\
+.59\end{array}$ \\
\hline
\end{tabular}
were derived from the expansion equations.

TABLE 4.-Rates of expansion at low temperatures

\section{MODERATE TEMPERATURE RANGES}

The following table describes nine samples of fused silica investi-

\begin{tabular}{|c|c|}
\hline Sample & Description \\
\hline $56 \ldots$ & er; made from transparent, water- \\
\hline 581 & Semiopaque fused silica rod, $9 \mathrm{~mm}$ diameter; grayish color, core much clearer than periphery, \\
\hline 601 & $\begin{array}{l}\text { Opaque fused silica rod, } 7 \text { by } 7 \mathrm{~mm} \text { cross section; grayish, milky white; made by fusing silica } \\
\text { round a central rod and blowing it into a mold, from which specimen was cut; annealed } \\
\text { at } 1,100^{\circ} \mathrm{C} \text {. for about one hour. }\end{array}$ \\
\hline $63^{3}$ & $\begin{array}{l}\text { Semiopaque fused silica rod, } 7 \mathrm{~mm} \text { diameter; grayish color, translucent core, fine longitudinal } \\
\text { striations; drawn from the original fusion and not subjected to any further treatment after } \\
\text { the drawing process. }\end{array}$ \\
\hline $71^{3}$ & $\begin{array}{l}\text { Opaque fused silica rod, } 7 \text { by } 8 \mathrm{~mm} \text { cross section; milky white; cut from a fusion molded into a } \\
\text { square section pipe; not annealed. }\end{array}$ \\
\hline $\begin{array}{l}1056 \mathrm{~A}^{4} \\
1057 \\
1057 \mathrm{~A}^{\mathrm{A}} \\
1102 \mathrm{~B}\end{array}$ & $\begin{array}{l}\text { Transparent fused silica rod, } 8 \mathrm{~mm} \text { diameter; not annealed. } \\
\text { Transparent fused silica rod, } 6 \mathrm{~mm} \text { diameter; annealed.2. } \\
\text { Cut from same rod as } 1057 \text {. } \\
\text { Transparent fused silica rod, } 5 \mathrm{~mm} \text { diameter; not annealed. }\end{array}$ \\
\hline
\end{tabular}
gated between room temperature and $300^{\circ} \mathrm{C}$. in an oil bath:

TABLE 5.-Description of samples

1 Contains 99.8 per cent $\mathrm{SiO}_{2}$. 3 Samples 63 and 71 were made from the same raw material.

Annealed by Thermal Syndicate (Lt...). "Preparation described in previous subsection. 
Figure 7 shows typical expansion curres on three sampies of fused silica. These specimens were obtained from diflerent sources.

Seventeen expansion tests were made on the samples of this group. From the expansion curves obtained in these determinations the arerage coefficients of expansion given in the following table were computed for various temperature ranges. For the range from 20 to $60^{\circ} \mathrm{C}$. the agreement in the coefficients of expansion is not as good as that for higher temperature ranges, due to the fact that the total expansion for the lowest range is extremely small.

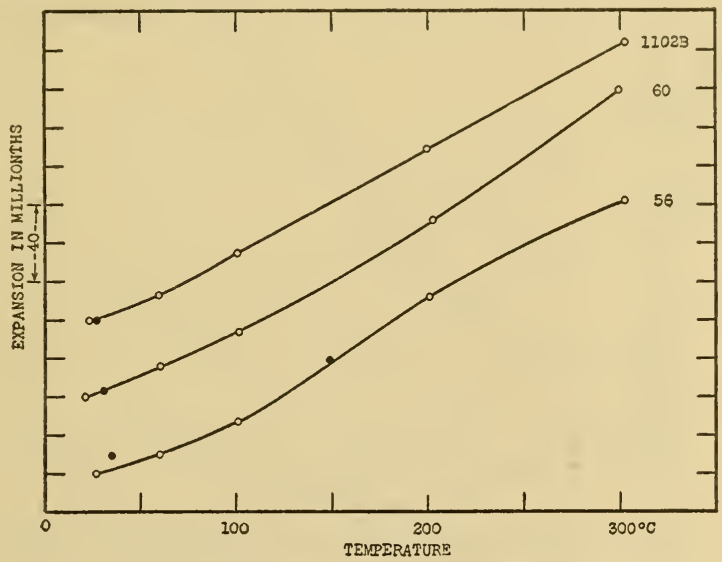

Fig. 7.-Linear expansion of three samples of fused silica

TABLE 6.-Average coefficients of expansion

Sample
(n)

1 Values on this horizontal line were obtained after heat treatment and a low-temperature test (see Table 2)

2 The coefficients of expansion of this sample were obtained after a low-temperature test (see Table 2). 
Table 7 gives average results for both transparent and nontransparent samples presented in Table 6. Each result represents an average of a number of determinations ( 5 to 9 tests). Average expansion curves derived from these results are shown in Figure 8.

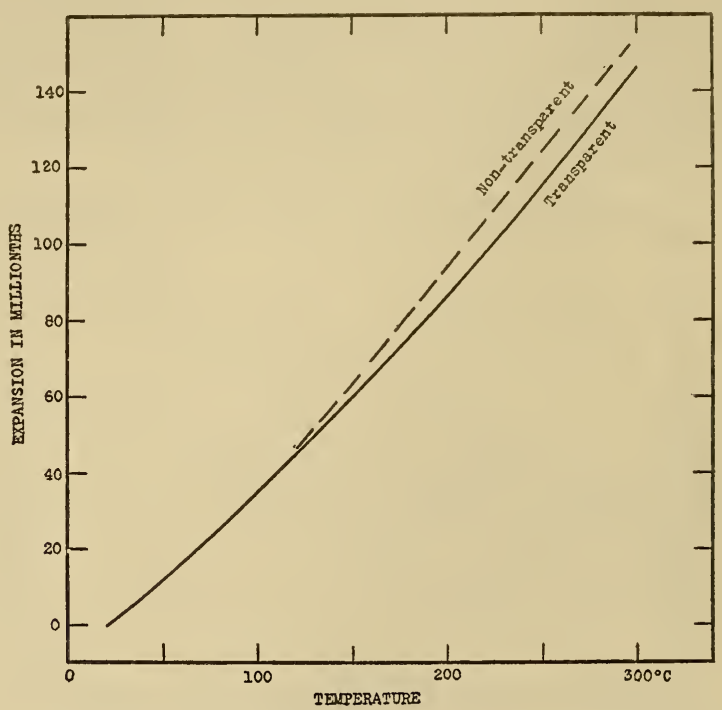

Fig. 8.-Average expansion curves of transparent and nontransparent samples of fused silica

TABLE 7.-Comparison of average coefficients of expansion of transparent and nontransparent samples

\begin{tabular}{|c|c|c|c|c|}
\hline \multirow{2}{*}{ Material } & \multicolumn{4}{|c|}{$\begin{array}{l}\text { A verage coefficients of expansion per } \\
\text { degree centigrade }\end{array}$} \\
\hline & $\begin{array}{l}20 \text { to } 60^{\circ} \\
\mathrm{C} .\end{array}$ & $\begin{array}{l}20 \text { to } 100^{\circ} \\
\text { C. }\end{array}$ & $\begin{array}{c}20 \text { to } 200^{\circ} \\
\text { C. }\end{array}$ & $\begin{array}{c}20 \text { to } 300^{\circ} \\
\text { C. }\end{array}$ \\
\hline $\begin{array}{l}\text { Transparent } 1 \text { (5 samples) } \\
\text { Nontransparent } 1 \text { (4 samples)...- }\end{array}$ & $\begin{array}{r}\times 10^{-6} \\
0.40 \\
.41\end{array}$ & $\begin{array}{r}\times 10^{-6} \\
0.45 \\
.44\end{array}$ & $\begin{array}{r}\times 10-8 \\
0.48 \\
.52\end{array}$ & $\begin{array}{r}\times 10^{-6} \\
0.52 \\
\quad .55\end{array}$ \\
\hline
\end{tabular}

1 The coefficients given are averages of all values of these samples of fused silica.

From an examination of the preceding table it is evident that the coefficients of expansion increase with temperature and that the coefficients of expansion of the transparent samples differ slightly from the coefficients of the nontransparent samples for corresponding temperature ranges.

At the end of the expansion tests the length of each sample varied slightly from the original length. The greatest rariation was found to be 0.003 per cent and the average variation \pm 0.001 per cent. 


\section{HIGH TEMPERATURE RANGES}

Table $S$ describes 12 specimens of fused silica on which expansion determinations were made over various temperature ranges between room temperature and $1,000^{\circ} \mathrm{C}$. 'These tests were made in an electrically heated air furnace. Samples 56, 58, 60, and $1057 \mathrm{~A}$ were examined from room temperature to $300^{\circ} \mathrm{C}$. before hightemperature tests were made. The previous subsection gives the results obtained on these four specimens over various temperature ranges between 20 and $300^{\circ} \mathrm{C}$.

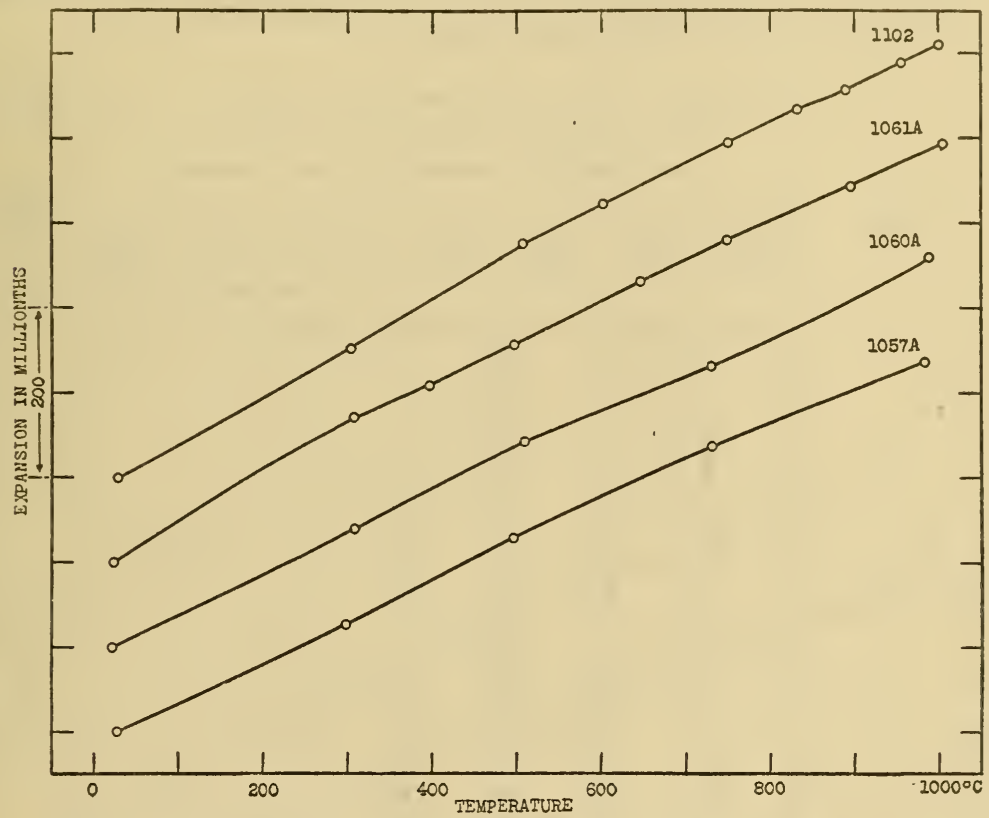

FIG. 9.-Linear expansion of four transparent samples of fused silica

TABLE 8.-Description of samples

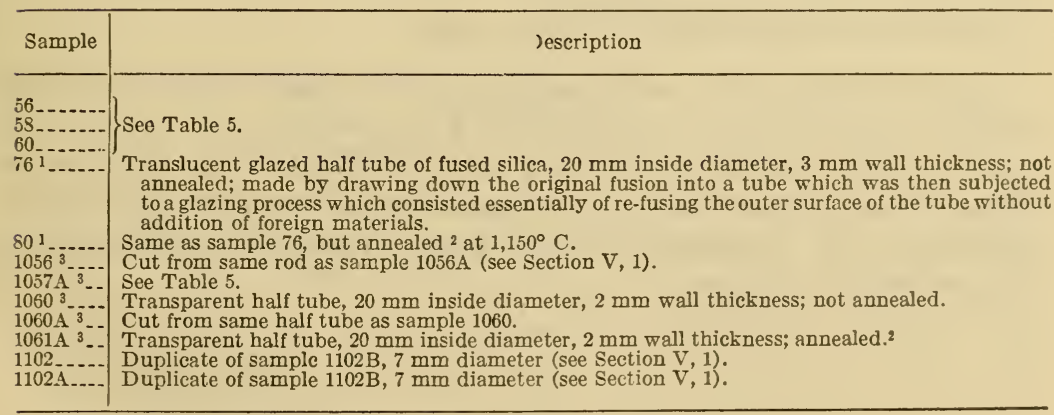

1. Samples 76 and 80 were prepared from the same raw material.

2 Annealed by Thermal Syndicate (Ltd.).

3 The preparation of this sample was the same as that for sample $1056 \mathrm{~A}$ or 1057 (see Section V, 1). 
Twenty-eight expansion tests were made on the samples of this group. Some of the expansion curves were irregular, especially at high temperatures on the first heating. Four expansion curves of transparent fused silica are shown in Figure 9, and two curves for nontransparent samples are given in Figure 10. Most of the curves are slightly concave downward. It is interesting to note that after cooling from $1,000^{\circ} \mathrm{C}$. to room temperature sample 1102 was found to be 0.003 per cent longer than its original length before heating, and that this increase in length remained constant at least 24 hours.

The average coefficients of expansion given in the following table were derived from the expansion curves.

TABLE 9.-Average coefficients of expansion

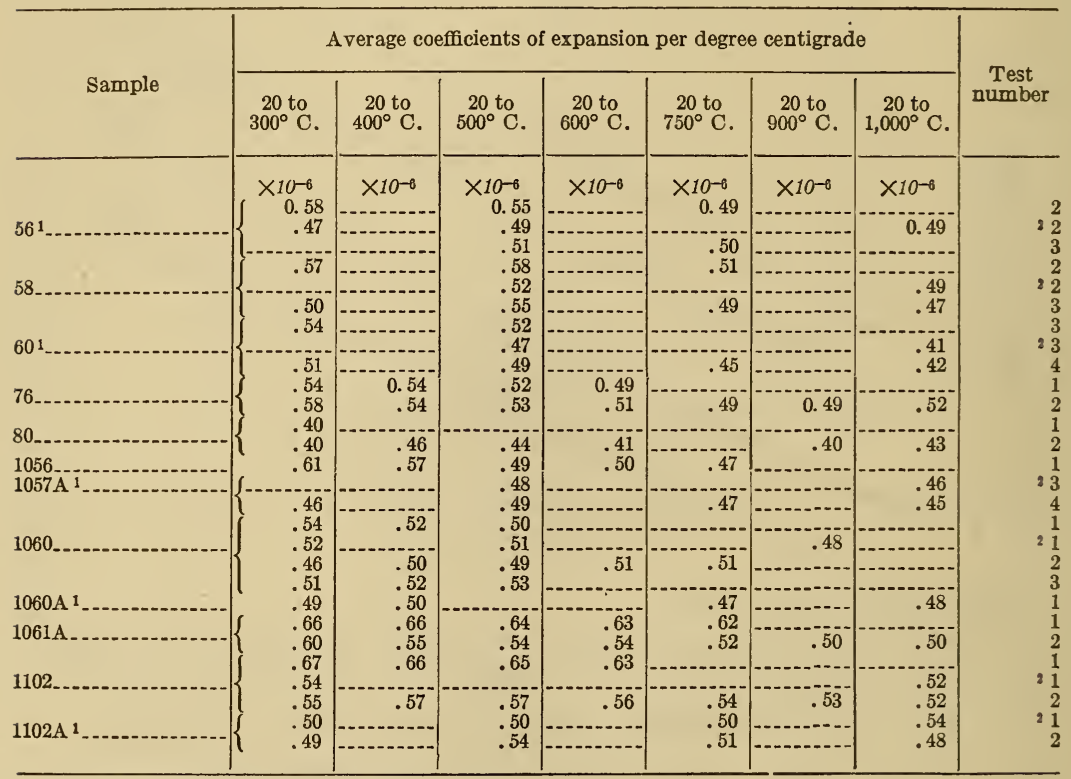

1 Heat treated before these tests (see Section III)

2 Values given on this horizontal line were obtained on cooling.

The following table gives a comparison of average values for transparent, nontransparent, annealed or heat-treated, and unannealed samples. Each value represents a mean of from 4 to 25 determinations. Mean values that were obtained from less than four determinations were omitted, for they were considered insufficient for representative averages. 
TABLE 10.-Comparison of average coeflicients of expansion of various samples

A. TRANSPARENT AND NONTRANSPARENT SAMPLES

\begin{tabular}{|c|c|c|c|c|c|c|c|}
\hline \multirow{2}{*}{ Material } & \multicolumn{7}{|c|}{ A verage coefficients of expansion per degree centigrade } \\
\hline & $\begin{array}{l}20 \text { to } \\
300^{\circ} \mathrm{C} .\end{array}$ & $\begin{array}{l}20 \text { to } \\
400^{\circ} \mathrm{C}\end{array}$ & $\begin{array}{l}20 \text { to } \\
500^{\circ} \mathrm{C} \text {. }\end{array}$ & $600^{\circ} \mathrm{C}$ & $\begin{array}{l}20 \text { to } \\
750^{\circ} \mathrm{C} \text {. }\end{array}$ & $\begin{array}{c}20 \text { to } \\
900^{\circ} \mathrm{C}\end{array}$ & $\begin{array}{l}20 \text { to } \\
1,000^{\circ} \mathrm{C}\end{array}$ \\
\hline $\begin{array}{l}\text { Transparent.-.- } \\
\text { Nontransparent.- }\end{array}$ & $\begin{array}{r}\times 10-0 \\
0.54 \\
.50\end{array}$ & $\begin{array}{r}\times 10^{-0} \\
0.56 \\
\end{array}$ & $\begin{array}{r}\times 10^{-6} \\
0.53 \\
.51\end{array}$ & $\begin{array}{r}\times 10^{-8} \\
0.56\end{array}$ & $\begin{array}{r}\times 10-0 \\
0.51 \\
.48\end{array}$ & $\begin{array}{c}\times 10^{-0} \\
-\end{array}$ & $\begin{array}{r}\times 10^{-6} \\
0.49 \\
.46\end{array}$ \\
\hline
\end{tabular}

B. ANNEALED 1 AND UNANNEALED SAMPLES

\begin{tabular}{|c|c|c|c|c|c|c|c|}
\hline $\begin{array}{l}\text { Annealed } 1 \text { Unannealed } \\
\text { Unann }\end{array}$ & $\begin{array}{r}0.51 \\
.55\end{array}$ & $\begin{array}{r}0.54 \\
.55\end{array}$ & $\begin{array}{r}0.52 \\
.53\end{array}$ & 0.53 & $\begin{array}{r}0.50 \\
.50\end{array}$ & & 0.47 \\
\hline
\end{tabular}

C. TOTAL SAMPLES

\begin{tabular}{l|l|l|l|l|l|l|l}
\hline All samples of subsection 3...-. & 0.53 & 0.55 & 0.52 & 0.53 & 0.50 & 0.48 & 0.48 \\
\hline
\end{tabular}

1 Includes heat-treated samples.

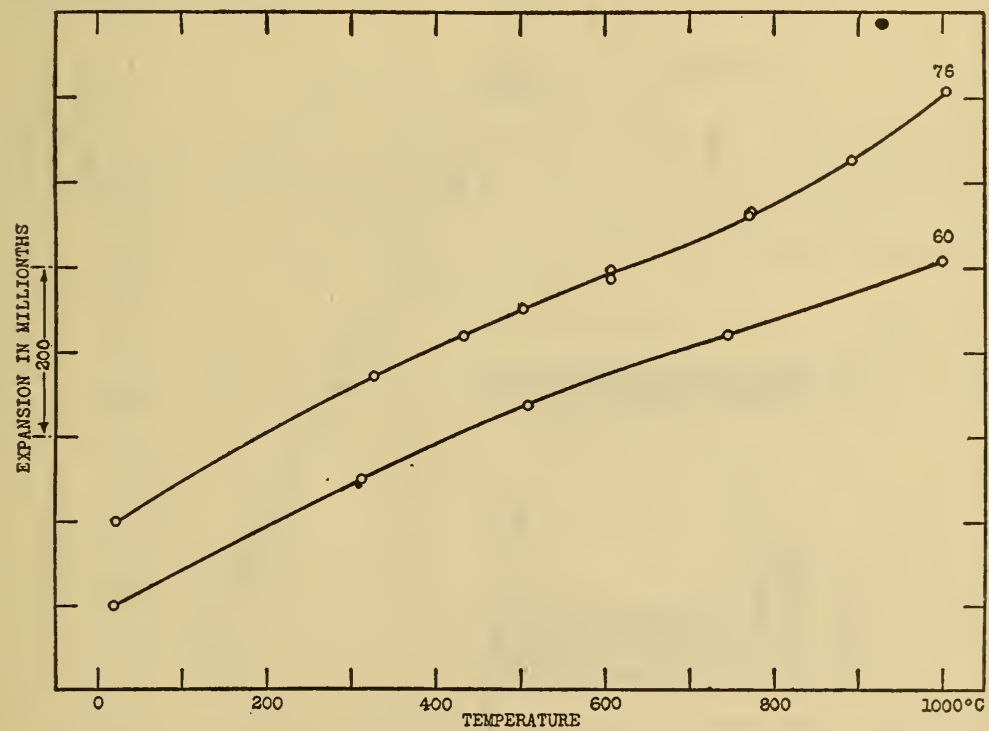

Fig. 10.-Linear expansion of two nontransparent samples of fused silica

The coefficients of expansion of the transparent samples are slightly larger than those of the nontransparent specimens. The coefficients of the annealed or heat-treated samples are generally slightly smaller than the coefficients of the unannealed specimens for corresponding temperature ranges. It is interesting to note that the average value $\left(0.53 \times 10^{-6}\right)$ obtained on all samples between 20 and $300^{\circ} \mathrm{C}$. is in agreement with the corresponding average value of all specimens of the preceding subsection. 


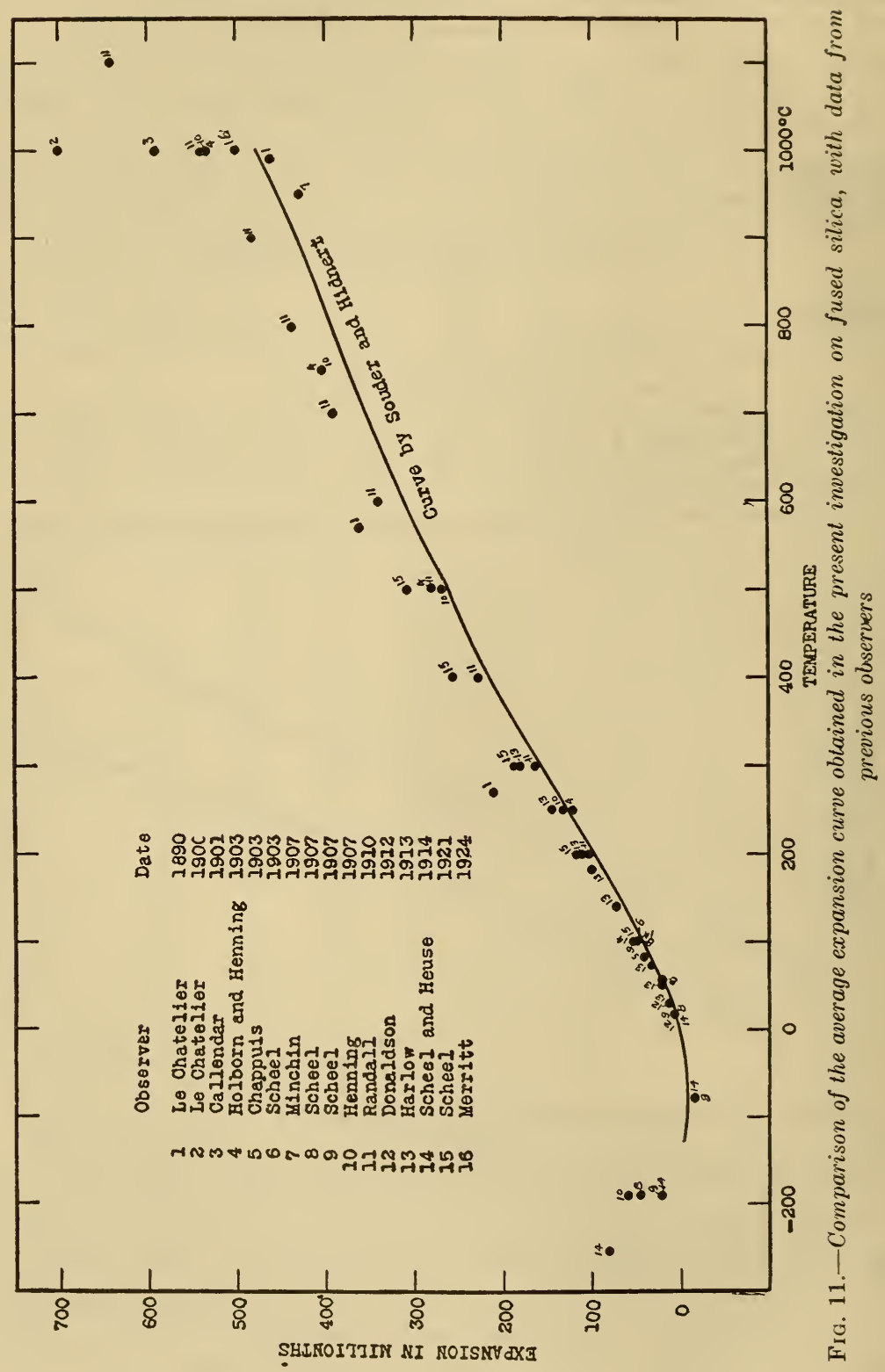


The length of each sample that was heat treated, as described in Section III, was found to be greater after the heat treatment. The average increase in length on the heat-treated samples ${ }^{3}$ was 0.011 per cent. After the expansion tests on the heat-treated samples of this subsection a slight additional change of length was observed on each specimen. The average change ${ }^{4}$ in length was less than 0.002 per cent.

The unannealed samples of fused silica indicated an increase in length after the expansion tests. The average increase in length was 0.006 per cent. Even the so-called annealed samples showed an increase in length after two heatings to $1,000^{\circ} \mathrm{C}$. and cooling to room temperature.

Holborn and Henning state that no after effects were observed after heating a rod of fused silica to $1,000^{\circ} \mathrm{C}$., and Minchin also found no after effects on a specimen heated to $950^{\circ} \mathrm{C}$. However, Callendar found the expansion to be reversible up to about $900^{\circ}$ C., but after cooling from higher temperatures an increase in length was observed at room temperature.

\section{COMPARISON OF RESULTS}

The arerage expansion curve given in Figure 11 was derived from the data in the preceding section. This curve may be considered to be the representative expansion curve of fused silica between -125 and $+1,000^{\circ} \mathrm{C}$. Available data obtained from previous investigators are included in this figure for comparison.

The curve shows a minimum point at about $-80^{\circ} \mathrm{C}$. Expansion occurs on heating fused silica above $-80^{\circ} \mathrm{C}$. or cooling below this temperature. The lower portion of the expansion curve is concave upwards, and the upper portion is concave downwards.

The values of nearly all observers agree closely up to about $300^{\circ} \mathrm{C}$. At higher temperatures greater variations may be seen. The results show the greatest scattering at $1,000^{\circ} \mathrm{C}$. At high temperatures the values obtained by several observers are greater than the average results of the present research. Le Chatelier was not certain that his sample of fused silica was entirely amorphous, and Randall states that a source of error possibly existed in his results due to the tilting of the interference system arising from unequal expansions in its supports.

Kaye ${ }^{5}$ states that it is probable that want of annealing is the cause in most cases of the anomalous results which have been obtained by some observers, and that this view is supported by the experiments of the National Physical Laboratory of England on the

\footnotetext{
${ }^{3}$ Includes samples 63,71 , and $1056 \mathrm{~A}$, which were not discussed in this subsection.

${ }^{4}$ An increase for every sample except one.

' Kaye, Phil. Mag., 20, p. 718, 1910; and Proc. Roy. Soc., A, 85, p. 430; 1911; or Nat'l Phys. Lab., 8, p. 89; 1912.
} 
behavior of specimens subject to a first heating as contrasted with their behavior on subsequent heatings. The work done in the present research confirms the experiments of the National Physical Laboratory.

Sosman ${ }^{6}$ presents a hypothesis which he states would explain the variation in expansion between different samples. This hypothesis supposes the silica atomtriplets $\left(\mathrm{SiO}_{2}\right)$ to be joined up into threads.

These threads form in the liquid state, and their formation may begin even in the vapor. In the liquid they are in a constant state of vibration and movement, with the oxygen pairs in haphazard and probably varying orientation relative to the thread. A drop of silica glass in the neighborhood of 1,700 to $1,800^{\circ}$ would resemble a mass of wriggling worms. The threads themselves not improbably have a helical twist.

If the temperature is rapidly lowered, the threads become less and less active, until at last the mass becomes like a compressed pad of wires, and we have "solid" silica glass. An intricately tangled mass of wires has some of the properties of a solid, even though the individual wires are flexible.

The drawing out of a lump of such glass into a rod might naturally be expected to disturb the haphazard arrangement of the threads and give some of them a prevailing orientation parallel to the rod. This would explain the difference in expansion parallel and perpendicular to the axis in silica rods or tubes, ${ }^{7}$ and the variation in expansion between different samples, indicated by some experiments. It perhaps will also aid in explaining the evidences of ribbonlike crystallinity in silica glass rods, observed by Rayleigh. ${ }^{8}$ The thread hypothesis is also in accord with the familiar habit of amorphous silica of condensing in fine, fluffy, or lintlike forms. It has even been obtained from the electric furnace in microscopically fibrous massive form, a fibrous glass, which is wholly noncrystalline to an $\mathrm{X}$-ray exposure of ordinary length, ${ }^{9}$ though showing traces of a structure under longer exposures.

Sosman states that his theory gives a satisfactory explanation for many phenomena of silica, such as the minimum in the temperaturevolume curve of silica glass, but he does not discuss this phenomenon. ${ }^{10}$

\section{SUMMARY}

This paper gives the results of an investigation on the thermal expansion of transparent and nontransparent samples of fused silica over various temperature ranges between -125 and $+1,000^{\circ} \mathrm{C}$. Serenteen samples of fused silica were studied. A total of 48 expansion tests were made on these specimens.

A detailed description of the apparatus and the methods used in this research and a summary of available data obtained by previous observers on the thermal expansion of fused silica are given.

\footnotetext{
6 Sosman, Jour. Frank. Inst., 194, p. 741; 1922.

${ }^{7}$ Callendar, Phil. Mag., 23, pp. 998-1,000; 1912. The difference is usually not so great as the first measurements indicated.

${ }^{8}$ Proc. Roy. Soc., London, A, 98, pp. 284-296; 1920.

${ }^{\theta}$ Photographs by Dr. E: W. Posnjak, of the Geophysical Laboratory, Carnegie Institution of Washington.

10 Will be discussed in a forthcoming publication by Doctor Sosman, of the Geophysical Laboratory, Carnegie Institution of Washington.
} 
A critical temperature or minimum length was found at about $-80^{\circ}$ C. Expansion occurred on heating fused silica above the critical temperature or cooling below this temperature. The coefficients of expansion are therefore positive above the critical temperature and negative below this temperature. The coefficients of expansion of the transparent samples differ slightly from the coefficients of the nontransparent samples.

In nearly every case the samples indicated a very small increase in length after heating to $1,000^{\circ} \mathrm{C}$. and cooling to room temperature.

Typical expansion curves are shown and discussed. Figure 11 indicates the authors' average expansion curve of fused silica and shows a comparison of the results of various investigators.

The following table gives a résumé of average coefficients of expansion derived from the data on all samples for various temperature ranges between 20 and $1,000^{\circ} \mathrm{C}$. For data at low temperatures the reader should refer to Tables 3 and 4 .

TABLE 11.-Résumé of average coefficients of expansion of fused silica

\begin{tabular}{|c|c|c|c|}
\hline $\begin{array}{c}\text { Temperature range in degrees } \\
\text { centigrade }\end{array}$ & $\begin{array}{l}\text { Average } \\
\text { coeffi- } \\
\text { cients } \\
\text { of expan- } \\
\text { sion per } \\
\text { degree } \\
\text { centi- } \\
\text { grade }\end{array}$ & $\begin{array}{l}\text { Temperature range in degrees } \\
\text { centigrade }\end{array}$ & $\begin{array}{l}\text { A verage } \\
\text { coeffi- } \\
\text { cients } \\
\text { of expan- } \\
\text { sion per } \\
\text { degree } \\
\text { centi- } \\
\text { grade }\end{array}$ \\
\hline $\begin{array}{l}20 \text { to } 60 \\
20 \text { to } 100 \\
20 \text { to } 200 \\
20 \text { to } 300 \\
20 \text { to } 400\end{array}$ & $\begin{array}{r}\times 10^{-8} \\
0.40 \\
.45 \\
.50 \\
.53 \\
.55\end{array}$ & $\begin{array}{l}20 \text { to } 500 \\
20 \text { to } 600 \\
20 \text { to } 750 \\
20 \text { to } 900 \\
20 \text { to } 1,000\end{array}$ & $\begin{array}{r}\times 10^{-8} \\
0.52 \\
.53 \\
.50 \\
.48 \\
.48\end{array}$ \\
\hline
\end{tabular}

\section{SELECTED BIBLIOGRAPHY OF EXPANSION APPARATUS}

Boeck, Trans. Amer. Ceram. Soc., 14, p. 470; 1912.

Chevenard, Rev. de Mét., 14, p. 610; 1917.

Day and Sosman, Amer. Jour. Science, 29 (No. 129), p. 111; 1910.

English Nat'l Phys. Lab. Report for 1914-15, p. 64.

Gray, Chem. and Met. Eng., 21, p. 667; 1919.

Holborn and Henning, Zeits. f. Instr., 32, p. 122; 1912.

Knerr, Chem. and Met. Eng., 26, p. 644; 1922.

Peters and Cragoe, B. S. Sci. Paper No. 393.

Sahmen and Tammann, Ann. d. Physik, 315, p. 879; 1903.

Scheel, Zeits. f. Physik, 5, p. 167; 1921.

Washington, September 21, 1925. 






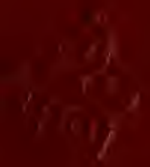

$$
\begin{aligned}
& =(10)
\end{aligned}
$$

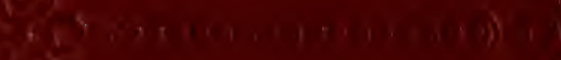

$$
\begin{aligned}
& 1,58
\end{aligned}
$$

